\title{
СИСТЕМА ПРИГОЛОСНИХ \\ З ПОГЛЯДУ ВИРАЖЕННЯ ВАЖЛИВИХ ТЕНДЕНЦІЙ РОЗВИТКУ ФОНОЛОГІЧНОЇ СИСТЕМИ УКРАЇНСЬКОЇ МОВИ
}

Здійснений у статті якісно-кількісний аналіз функціонування системи приголосних сучасної української літературної мови дає підстави твердити про наявність тенденції до максимальної гучності й вокалічності української вимови як важливого складника української милозвучності. Серед найважсливіших свідчень зазначених тенденцій: наявність у фонологічній системі сучасної української мови специфічних дзвінких африкат

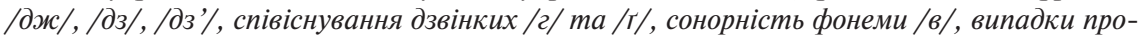
гресивної асиміляції за дзвінкістю, переважання серед регресивних змін асиміляцій за дзвінкістю, виявлення прагнення до максимальної гучності й вокалічності в процесах дисиміляцї та дієрези (спрощення), визнане нормативним оглушення дзвінких приголосних в абсолютному кінці слова.

Ключові слова: фонологічна система української мови, гучність, вокалічність, милозвучність, асиміляція за дзвінкістю, дисиміляція, спрощення.

Skab M. S. System of Consonants in the Context of Expression of Important Trends for Development of the Fonological System of the Ukrainian Language.

The topicality of the work is, in particular, in systematizing the sound phenomena and processes in the system of consonants while teaching the course "Introduction to Linguistics» in terms of identifying the important differential feature of the modern Ukrainian language.

The qualitative and quantitative analysis of the functioning of the system of consonants in the modern Ukrainian literary language conducted in this article gives grounds to assert that there is a strong tendency towards the maximum volume and vocality of the Ukrainian pronunciation as an important component of Ukrainian sonority, distinguishing the Ukrainian language from among other Slavic and non-Slavic languages, in particular clearly contrasting it with the Russian language. Among the most important evidence of these tendencies are the presence in the phonological system of the modern Ukrainian language of the specific voiced africates $/ \partial x /, / \partial 3 /$, $/ \partial_{3} \%$, the coexistence of the voiced $/ 2 /$ and $/ \mathrm{r} /$, the phonemic sonority of $/ \mathrm{b} /$, the unique but very characteristic cases of progressive assimilation by sonority, the predominance of assimilation by sonority among regressive assimilations, existing trend for maximum volume and vocalism in the processes of dissimilation, inherent in the Ukrainian language, and of simplification, devocalization of voiced consonants at the absolute end of the word, recognized as normative in the modern Ukrainian literary language.

The coverage of these facts and processes in the propaedeutic course "Introduction to Linguistics», according to the authors of the article, is an important component of the formation of freshmen's beliefs about the systemic nature of a language as a whole and its phonological system, in particular, the laws of historical development of the language, determined by the formation and evolution of the mentality of the ethnic group as native speakers substantial differential sign of the Ukrainian language.

Key words: phonological system of the Ukrainian language, volume, vocality, euphony, assimilation by sonority, dissimilation, simplification.

\section{Ветуп}

Уперше про С. І. Дорошенка я почув у вересні 1975 року, коли світлої пам'яті Дмитро Григорович Бучко на занятті зі вступу до мовознавства для студентів-першокурсників Чернівецького університету згадав про Сергія 
Скаб М. С. Система приголосних з погляду вираження важливих тенденцій розвитку фонологічної системи...

Івановича як одного із співавторів підручника з цієї дисципліни. Пригадую, що Дмитро Григорович з-поміж інших наукових чеснот відзначив особливий викладацький хист С. І. Дорошенка, пообіцявши активно використовувати під час практичних занять методичні знахідки Сергія Івановича. Так незабаром і сталося: наш викладач, скориставшись розробленою С. I. Дорошенком методикою опису та інтерпретації комбінаторних фонетичних процесів (пізніше описаною автором у статті «Практичне освоєння процесів асиміляції і дисиміляції у вступному курсі загального мовознавства» (Дорошенко, 2009: 220-228), познайомив нас із струнким, логічним та, що дуже важливо, наочним алгоритмом визначення таких процесів. Цей момент, як розумію зараз, був одним із перших важливих раціональних і водночас емоційних аргументів на шляху усвідомлення логічності й системності ладу мови, урешті-решт, визначив у майбутньому мою наукову та викладацьку долю як філолога-лінгвіста. Саме тому, отримавши запрошення до участі в збірнику наукових праць на пошану Сергія Івановича Дорошенка, я вирішив викласти міркування, які народилися під безпосереднім впливом відомого вченого й методиста і набули певної викінченості впродовж багаторічного викладання курсів вступу до мовознавства, загального мовознавства, фонетики й фонології сучасної української літературної мови.

Під час знайомства першокурсників з основами загального мовознавства на кожному занятті потрібно вести свідому й планову роботу водночас у кількох напрямках: постійно переконувати їх у закономірній системності мовних явищ, у тому, що мова загалом постійно змінюється, а розвиток конкретної мови відбиває специфіку становлення, розвитку, а відтак і ментальних особливостей етносу, що є її носієм. Дуже важливо знайти такі форми інтерпретації функціонування окремих одиниць тих чи тих рівнів мовної структури, які допоможуть переконати слухачів як у системності мови загалом, так і в закономірному й системному вияві в конкретних мовних фактах загальних (часто специфічних) тенденцій розвитку конкретної мови, групи або сім'ї мов. Ще в студентські роки звернувши увагу на характерний приклад того, що кожна мова торує свій шлях розвитку, пізніше в одній із статей ми так схарактеризували цей процес: «У сучасних слов'янських мовах порізному видозмінилося праслов'янське слово *bьčela. У білоруській (пчала), російській, болгарській та сербській мовах (пчела) у цьому слові відбулася регресивна асиміляція за глухістю. У польській мові поруч оглушеного звука витворився призвук - pszczoła. У чеській мові відбулася дисиміляція за способом творення: včela. І лише в українській мові відбулася достатньо рідкісна прогресивна асиміляція за дзвінкістю: бджола» (Гайсенюк \& Скаб, 2012: 52]. I хоча в українській мові зафіксовано й інші результати, про що зокрема читаємо в авторитетному академічному виданні: «В окремих словах одні діалекти в нових групах приголосних переживали регресивну асиміляцію, а інші - прогресивну, як-от у давньоруському іменникові бьчела. Регресивну асиміляцію в ньому засвідчують такі староукраїнські написання: пчолы, пчолами, пчоль (ВС, 1347, АЗР, I, 18), пчоли (Рус, гр. 1456, 105), пчол (АЖ, 1582, 45); пор. рос. пчела, блр. пчала, укр. діал. пчола (Ж., II, 792; Гр., III, 504), 
пчільня, пчельня. Прогресивну асиміляцію (бъчєла $\rightarrow$ бджола) передають написання бчолы, бчоль (ВС, 1347; АЗР, I, 7; АЖ, 1584, 76), бчол (Рус, гр. 1458, 109)», усе ж саме наслідки прогресивної асиміляціїі «закріпились як норма і в сучасній українській літературній мові: бджола (УРС, I, 1953, 38; СУМ, I, 1970, 117)» (Жовтобрюх \& Русанівський \& Скляренко, 1979: 208). Ми переконані, що незвичайні напрямок та характер зафіксованої взаємодії приголосних в українській мові не є випадковими, а навпаки відбивають дуже сильну властиву саме українській мові фонологічну тенденцію - прагнення до максимальної гучності й вокалічності ${ }^{1}$ вимови, що $\epsilon$, своєю чергою, ядерним виявом такої визначальної для нашої мови ознаки, як ії милозвучність, досить повно й різнобічно описаної лінгвістами (див. про це, зокрема: Гайсенюк \& Скаб, 2012; Калашник, 2007; Мосенкіс, 2002; Огієнко, 1923; Прокопова, 2010; Самійленко, 2003; Сербенська, 2016; Тимошенко, 1952; Тоцька, 2000; Фаріон, 2007).

Актуальність порушуваної проблеми виявляється зокрема в тому, що запропонований підхід дає підстави твердити, що милозвучність української мови, з одного боку, виникла як питоме продовження найважливіших рис праслов'янщини, а, з другого боку, аналізовані складники милозвучності розвинулися як протиставлення в шляхах розвитку фонологічної системи української та російської мов, а відтак вивчення цих аспектів милозвучності дозволить системно спростовувати лукаві тези про виняткову близькість (навіть тотожність) мов, належність українців та росіян до одного етносу тощо. Як слушно твердить Н. І. Тоцька: «Те, що українська мова відзначається особливою милозвучністю, відомо здавна, i, здається, ніхто не сумнівається в цьому тепер, хоч найменше можуть про це судити самі носії української мови, оскільки для них мова знаряддя щоденного спілкування, а не об'єкт для спостереження» (Тоцька, 2000: 3). Саме тому з погляду лінгводидактики дуже важливо прищепити філологам-першокурсникам і майбутнім учителям-словесникам свідоме переконання про милозвучність як визначальну рису української мови.

Дослідники української милозвучності однією з ії визначальних характеристик називають саме прагнення до гучності. Показовими в цьому сенсі вважаємо зокрема твердження Н. Тоцької про те, що «милозвучність української мови забезпечує передусім гучність, яка має різноманітні виявлення: виразна повнозвучна вимова голосних і приголосних у сильних і слабких позиціях, порівняно невелика кількість збігів кількох приголосних, плавна акцентно-ритмічна структура слова, наспівна мелодика тощо» (Тоцька, $2000,4)$ та О. Сербенської: «поняття милозвучності слід визначати, беручи

${ }^{1}$ Терміни гучність і вокалічність сучасні лінгвісти трактують так: «Гучність мови полягає у виразній вимові голосних та приголосних, невеликому збігові приголосних, плавній акцентно-ритмічній структурі [...]. Вокалічність української мови зумовлена сонорними приголосними, відсутністю оглушення дзвінких у кінці слова та в середині перед наступним глухим, паралельними формами на зразок у-в, уві-вві, 3-зі-із-зо, ж- же, б-би, від-віді-од-оді, ся-сь та ін.» (Микитюк, 2012: 220-221). 
Скаб М. С. Система приголосних з погляду вираження важливих тенденцій розвитку фонологічної системи...

до уваги комплекс показників, а не обмежуватися якоюсь однією, хоч і дуже важливою ознакою. Основними рисами зокрема є гучність, вокальна гармонія, плавність, тенденція до відкритості складів, до наростання сонорності у внутрішніх складах, акцентно-ритмічна структура тощо» (Сербенська, 2016: 259). Цілком природно постає проблема системного вираження прагнення до максимальної гучності та вокалічності як ядерних виявів української милозвучності в конкретних фонетичних процесах, які в різні часи відбувалися в нашій мові, про що писали українські дослідники (див. наприклад: Тимошенко, 1952; Мосенкіс, 2002; Калашник, 2007; Гайсенюк \& Скаб, 2012).

\section{Методи та методики дослідження}

Метою пропонованої розвідки є аналіз комбінаторних фонетичних процесів у системі приголосних української мови на тлі аналогічних явищ, що трапляються в інших мовах, з погляду підтвердження визначеної тенденції до максимальної гучності (чи сонорності). Для реалізації поставленої мети проаналізуємо вияви фонетичних процесів, що переважно відбулися після занепаду зредукованих і повною мірою формували специфічне обличчя фонологічної системи української літературної мови. Одразу ж наголосимо, що такий аналіз уважаємо важливим складником навчально-виховної роботи зі студентами-першокурсниками в процесі вивчення ними курсу «Вступ до мовознавства», спрямованої на формування в них системного погляду на милозвучність української мови як одну з визначальних їі відмінних ознак. Наші міркування й твердження будемо грунтувати й вибудовувати на: конкретних фактах й теоретичних узагальненнях, викладених свого часу глибоким лінгвістом, управним лінгводидактом, палким оборонцем та популяризатором української мови Іваном Огієнком у праці «Наочна таблиця милозвучності української мови. Для школи й самонавчання» (Огієнко, 1923); поглядах на становлення фонологічної системи української мови, вироблення іiі сучасних орфоепічних норм, зокрема викладених в авторитетній академічній праці «Історія української мови. Фонетика» (Жовтобрюх \& Русанівський \& Скляренко, 1979); розвідках мовознавців, що в різні часи опрацьовували цю проблему.

\section{Результати та дискусії}

Передусім наголосимо, що прагнення до максимальної гучності виявляється в якісно-кількісній специфіці українського консонантизму. Так саме фонологічній системі української мови властиві специфічні дзвінкі

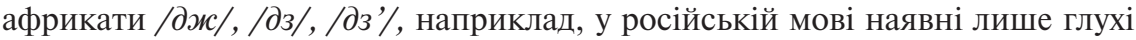
африкати, співіснування в системі дзвінких фонем / / $/$ та $/ \check{\Gamma}$, у російській лише /г/. Безперечно, вища гучність порівняно з іншими мовами притаманна українській фонемі /в/ (на відміну від дзвінкої в російській мові), що зумовлює низку особливих звукових явищ: нескладотвірний позиційний варіант [ў], орфоепічне чергування $в-y$ тощо.

Не менш цікаві вияви прагнення українців до забезпечення максимально гучного вимовляння знаходимо, аналізуючи комбінаторні фонетичні процеси, притаманні українській мові. 
Як слушно стверджував свого часу I. Огієнко: «51. Приголосний звук, збігаючись із приголосним, звичайно уподібнюється йому за звучністю, якістю та м'якістю. Уподібнення постає з фізіологічних причин і в мові нашій відоме з доісторичного часу [...] 53. Українська мова любить сполучення приголосних звуків лише однакові: дзвінких із дзвінкими, тихих із тихими, шиплячих із шиплячими, свистячих із свистячими, твердих із твердими й м'яких із м'якими. Таке сполучення настає не тільки у слові, але й у словах, що стоять поряд - у сполученні кінця попереднього слова й початку подальшого (коли тільки між словами немає паузи)» (Огієнко, 1923).

Доволі часто в таких процесах помітним є саме прагнення мовців підвищити або бодай зберегти гучність вимови, притаманну вихідним ії варіантам. Так, практично тотожною $з$ погляду вияву тенденції до максимальної гучності в українській мові зміни прасл. *bsčela $\rightarrow$ укр. норм. бджсла $є$ прогресивна асиміляція за дзвінкістю Гания $\rightarrow$ Гандзя, де під впливом попереднього сонорного наступний глухий африкат змінюються на специфічно український дзвінкий².

Не менш показовими є дуже поширені в українській мові випадки регресивної асиміляції за дзвінкістю, які докладно описано в наукових працях: «Одним із важливіших наслідків процесу регресивної асиміляції є зміна глухого приголосного у дзвінкий в позиції перед дзвінким приголосним. Її відбивають ще пам'ятки давньоруської писемності, напр.: здоровье (Нап. 1151; Хр., 28) із сьдоровьє, зде (См. гр. 1229, .21), здравь (Пролог 1262), збирають, з горчииами (Кормча 1282). Староукраїнські писемні пам'ятки наслідки цієї асиміляції засвідчують уже досить часто, як-от: прозбу (ВС, 1347; АЗР, 1,8), здєржат (Р., 1388, 43), збъгль (гр. 1435, 134), здоровью (гр. 1435, 132), з дубровами, з бортными зємлАми, з бобровыми гоны (Рус, гр. 1407, 35), од духа (KA, 1560, 291), оддълено (60), згорнєшь (283), згрєшили (253), здыхают (265), прозбу (АЖ, 1584, 82), з гнєву (71), збыли (120), з двора (1583, 51), од дожчов (АЖ, 1582, 40), прозба (Син., XVII, 150), збираль (Пер., п. XVII, 29), позбывавъ, з бчолами (АПГУ, XVII, I, 78), з допущеня (164), назбирати (I. Вел., к. XVII - п. XVIII, 66), згрьшаєть (K. 3., к. XVII - п. XVIII, 89), з запасомъ (268), з дымомъ (226), прозбою (Л. Вел. 1720, 21). Наслідки цієї асиміляції в староукраїнських пам'ятках найповніше відбивають прийменники й префікси» (Жовтобрюх \& Русанівський \& Скляренко, 1979: 205). Думаємо, що важливим аргументом на підтвердження висуненої гіпотези є визнання, що саме «Асиміляція в групах глухий + дзвінкий приголосний набула в українській мові значення ії загальної фонетичної норми: [бород’бa] $\leftarrow$ [боротьба], $[$ молод'ба] $\leftarrow$ [молотьба], $[$ проз'ба] $\leftarrow$ [просьба], [здоровий] $\leftarrow[$ сьдоровьи], [з гори $] \leftarrow[$ съ горы] (Жовтобрюх \& Русанівський \& Скляренко, 1979: 206).

Цілком погоджуючись із твердженням I. Огієнка, що «при зустрічі приголосних звуків дзвінкі перед тихими самі стають тихими, а тихі перед

2 До речі, Ю. Шевельов бачив додаткові причини цього авища в афективності форми імені: У випадку імені Гандзя, посталого, мабуть, із *Hancja, з суфіксом -(ь) с- слід зважати на афективний характер цієї форми, що міг спричинитися до подзвінчення (Шевельов, 2002: 609). 
Скаб М. С. Система приголосних з погляду вираження важливих тенденцій розвитку фонологічної системи...

дзвінкими стають дзвінкими (дзвінкі - дзвіночки: б, в, г, г, д, ж, з, ч; тихі: п, ф, х, к, т, Ш, с, ц): прозьба (пишемо просьба), дьохтем (дьогтем), лехкий (легкий), озьде (осьде), ягби (якби), Велигдень (Великдень), мабудь (мабуть, має буть), хто (з къто), тхір (з дъхорь), тхнути (дъхноути), стухнути і т. п» (Огієнко, 1923), звертаємо увагу на те, що регресивна асиміляція за глухістю відбувається в українській мові своєрідно, відмінно ніж у інших слов'янських мовах: «Відбувалася регресивна асиміляція і в групах дзвінкий + глухий приголосний, хоч, певно, вона, як свідчать сучасні українські діалекти, не була такою послідовною, як у групах глухий + дзвінкий» (Жовтобрюх \& Русанівський \& Скляренко, 1979: 206).

Серед типових для української мови регресивних асиміляцій, безсумнівно, переважають саме асиміляції за дзвінкістю, водночас (на відміну, наприклад, від російської мови) обмежено виявляється регресивна асиміляція за глухістю. Літературно нормативними є лише кілька випадків такої асиміляції всередині слова: нігті, кігті, вогко, легко, які, проте, некоректно інтерпретувати як просто заміну дзвінкої вимови на глуху, адже, як слушно стверджував свого часу саме С. І. Дорошенко, відбувається ще й уподібнення за місцем і способом творення: «Зіставлення засвідчує, що у вихідному (фонемному) стані, тобто на рівні мови, розглядувані сполуки [/г/+/к/ - M. С.] різняться за місцем артикуляції, за участю голосу і шуму й за способом артикуляції. [...] Тим часом у вимові (на мовленнєвому рівні) їхня відмінність утрачена: глоткова дзвінка фонема /г/ за місцем артикуляції виявляється в задньоязиковому, а за участю голосу і шуму - у глухому варіанті - [х] (Дорошенко, 2009: 222).

Думаємо, що своєрідно тенденція до максимальної гучності (підтримувана й спільнослов'янською тенденцію до висхідної гучності, що виявлялася в дії закону відкритого складу) представлена і в основних типових для української мови процесах дисиміляції. Після посталого після занепаду зредукованих незручного, суперечливого висхідній гучності поєднання приголосних саме в українській мові відбулося їх розподібнення, з урахуванням поряд з іншими характеристиками й характеристик консонантів за гучністю (сонорністю). Тут ми маємо на увазі передусім загальновизнаний факт вищої гучності проривних порівняно зі щілинними. Відповідно типові для української мови дисиміляції /кт/ $\rightarrow$ [хт], /чн/ $\rightarrow$ [шн], /тт/ $\rightarrow$ [ст] $(/$ дт/ $\rightarrow$ $[\mathrm{cт]})$ є випадками «покращення» милозвучності вимови шляхом розподібнення звукосполучень проривний+проривний у щілинний+проривний, що з погляду гучності (сонорності) може бути представлене як регресивне розподібнення за гучністю: поєднання двох однакових за гучністю звуків змінюється поєднанням менш гучного з більш гучним, що є виявленням тенденції до висхідної гучності звуків у складі.

Функціонування тих же закономірностей спостерігаємо і в дуже поширених в українській мові явищах дієрези, які традиційно в українській лінгвістиці та лінгводидактиці називають спрощеннями. Як зауважував I. Огієнко: «41. Українська мова не терпить немилозвучного збігу двох або трьох приголосних (порівняйте ново-церковнослов'янське: в предпразднственний 
сей день, разжзи утроби); у разі такого збігу один із приголосних звуків або уподібнюється сусідньому, або, уподібнившись, зникає, або між ці приголосні вставляються голосні $o$ чи $е$. 42. У немилозвучних сполученнях жљди, здн та стн зубні звуки $\partial, m$ постійно зникають перед $H$, і ми їх звичайно й не пишемо: тижня (тиждень), борозна, пізно, первісний, зловісний, ані шелесне, тісний, чесний, почесний, капосник, напасник, пропасниия, власний, звісний, сучасний, водохресний, персня, ненависний, корисний; так само: вісник, існувати, дійсний, власний, хресний» (Огієнко, 1923). Такі явища мовознавці однозначно трактують як вияви милозвучності, наприклад, в академічній історії мови читаємо: «Нові групи приголосних, що постали в давньоруській мові внаслідок утрати зредукованих, не завжди легко вимовляти, деякі з них виявилися з цього погляду досить складними, тому, природно, окремі звуки при їх вимові випадали, пропускалися. Отже, разом із появою нових груп приголосних розпочалося і їх спрощення. Як правило, спрощувалися тризвукові сполучення, середнім приголосним у яких був проривний $[\mathrm{d}]$, [t], a кінцевим - сонорний [п], [1] або африката [с̌] (Жовтобрюх \& Русанівський \& Скляренко, 1979: 201).

Тенденція до збереження максимальної гучності виявляється в притаманній саме українській літературній мові дзвінкій вимові приголосних в абсолютному кінці слова (наприклад, так про це писав I. Огієнко: «53. Літературна українська мова на кінці слів знає переважно дзвінку вимову приголосних: лоб, кров, сад, луг (а не лоп, кроф, сат, лух)» (Огієнко, 1923), що знову ж таки протиставляє українську багатьом іншим слов'янським та неслов'янським мовам. Таку рису категорично проголошено як одну з питомих ознак сучасної української літературної мови, хоча не всі мовознавці іiї беззастережно визнають, посилаючись на факти діалектного та розмовного мовлення. Зокрема до такої позиції в одній зі статей з промовистою назвою «Оглушення дзвінких у кінці слова - орфоепічна норма української мови» схиляється й С. І. Дорошенко (Дорошенко, 2009: 12-18).

\section{Висновки}

Отже, якісно-кількісний функційний аналіз системи приголосних сучасної української літературної мови дає підстави твердити про наявність сильної тенденції до максимальної гучності й вокалічності української вимови як важливих складників української милозвучності, що вирізняє українську мову з-поміж інших слов'янських та неслов'янських мов, виразно протиставляючи іiї російській мові. Серед найважливіших свідчень зазначених тенденцій: наявність у фонологічній системі сучасної української мови специфічних дзвінких африкат /дж/, /дз/, /дз', співіснування дзвінких /г/ та /г/, сонорність фонеми /в/, унікальні, але дуже характерні випадки прогресивної асиміляції за дзвінкістю, переважання серед регресивних асиміляцій асиміляції за дзвінкістю, виявлення прагнення до максимальної гучності й вокалічності в процесах дисиміляції та дієрези (спрощення), типових для української мови, визнане нормативним у сучасній українській літературній мові оглушення дзвінких приголосних в абсолютному кінці 
слова. Висвітлення цих процесів у пропедевтичному курсі «Вступ до мовознавства» $є$ важливим складником формування в першокурсників переконання про системність мови загалом та її фонологічної системи зокрема, закономірності історичного розвитку мови, детермінованого становленням та еволюцією ментальності етносу, що є ії̈ носієм, вагомим свідченням самобутності української мови.

Перспективи подальшого дослідження бачимо в аналізі під запропонованим кутом зору української системи вокалізму, вивченні випадків численної взаємодії приголосних та голосних фонем, порівнянні й зіставленні виявлених фактів та закономірностей із такими ж явищами в інших (слов'янських та неслов'янських) мовах.

\section{ЛІТЕРАТУРА}

1. Гайсенюк О., Скаб М. Милозвучність української мови на тлі інших слов'янських мов. Вісник Львівського університету. Серія філологічна. 2012. Випуск 56. Частина 1. C. 48-55. URL.: http://nbuv.gov.ua/UJRN/Vlnu_fil_2012_56(1)_8. 2. Дорошенко С. I. Наукові простори: вибрані праці. Харків: «Новое слово», 2009. 485 с. 3. Жовтобрюх М. А., Русанівський В. М., Скляренко В. Г. Історія української мови. Фонетика. Київ: Наукова думка, 1979. 367 с. 4. Калашник В. С. Милозвучність. Українська мова. Енциклопедія. Київ: Вид-во «Українська енциклопедія» імені М. П. Бажана, 2007. 358 с.. 5. Микитюк О. Вплив суспільних чинників на фонетичну систему української мови. Мова і суспільство. 2012. Вип. 3. С. 218-223. URL.: http:// nbuv.gov.ua/UJRN/mis_2012_3_28. 6. Мосенкіс Ю. Л. Проблема милозвучності української мови: теоретичні й методичні аспекти. Наукові записки. Том 20. Філологічні науки. / Національний університет «Києво-Могилянська академія». 2002, С. 23-25. 7. Огієнко I. Наочна таблиця милозвучності української мови Для школи й самонавчання. Жовква. Друкарня Отців Василіян, 1923. 8. Прокопова Л. Ще раз про основний параметр милозвучності української мови. Українська мова, 2010, № 2. C. 76-80. URI: http://dspace.nbuv.gov.ua/handle/123456789/37707. 9. Самійленко В. Дбаймо про фонетичну красу мови. Урок української. 2003. № 2. С. 28-29. 10. Сербенська О. Основні параметри милозвучності української мови. Теле- та радіожурналістика. 2016. Випуск 15. С. 258-266. URI: http://nbuv.gov.ua/UJRN/Tir_2016_15_38. 11. Тимошенко Т. Д. Засоби милозвучності (евфонії) української мови. Українська мова в школі, 1952. № 4. C. 3-14. URI: http://zbruc.eu/node/41915. 12. Тоцька Н. I. Засоби милозвучності української мови. Українське мовознавство. Вип. 22. Київ, 2000. С. 3. URI: http://www.мова.укр/htm/04/71.htm. 13. Фаріон I. Д. Вслухаймось у звуки крізь віки. Український смисл: Науково-популярний лінгвокультурологічний щоквартальник. Дніпропетровськ: Вид-во ДНУ. 2007. № 4. С. 2-14. 14. Шевельов Ю. Історична фонологія української мови: пер. з англ. пер.: С. Вакуленко, А. Даниленко; Канад. ін-т укр. студій, Схід. ін-т українознав. ім. Ковальських, Харків. іст.-філол. т-во. Харків: Акта, 2002. XII, $1054 \mathrm{c}$.

\section{REFERENCES}

1. Haiseniuk, O., Skab M. (2012). Mylozvuchnist ukrainskoi movy na tli inshykh slovianskykh mov. [Euphony of Ukrainian language in the context of other Slavic languages]. Visnyk Lvivskoho universytetu. Seriia filolohichna. [Visnyk of the Lviv University. Series Philology], 56, 1, 48-55]. Retrieved from http://nbuv.gov.ua/UJRN/Vlnu_fil_2012_56(1)_8. [In Ukrainian]. 2. Doroshenko, S. I. (2009). Naukovi prostory: vybrani pratsi. [Scientific Spaces. Selected works]. Kharkiv: «Novoe slovo» [In Ukrainian]. 3. Zhovtobriukh, M. A., 
Rusanivskyi V. M., Skliarenko V. H. (1979). Istoriia ukrainskoi movy. Fonetyka. [History of the Ukrainian language. Phonetics]. Kyïv: Naukova dumka 4. Kalashnyk, V. S. (2007) Mylozvuchnist. [EUPHONY]. Ukrainska mova. Entsyklopediia. [Ukrainian Language. Encyclopedia]. K.: Vyd-vo «Ukrainska entsyklopediia» imeni M. P. Bazhana, 358 [in Ukrainian]. 5. Mykytiuk, O. (2012). Vplyv suspilnykh chynnykiv na fonetychnu systemu ukrainskoi movy. [The influence of social factors on the phonetic system of the Ukrainian language]. Mova i suspilstvo. [Language and Society], 3, 218-223. Retrieved from http://nbuv.gov.ua/ UJRN/mis_2012_3_28. [In Ukrainian]. 6. Mosenkis, Yu. L. (2002). Problema mylozvuchnosti ukrainskoi movy: teoretychni y metodychni aspekty. [The problem of the Ukrainian language euphony: theoretical and methodic aspects]. Naukovi zapysky. Tom 20. Filolohichni nauky. / Natsionalnyi universytet «Kyievo-Mohylianska akademiia». [«NaUKMA Research Papers. Linguistics»], 20, 23-25 [In Ukrainian]. 7. Ohiienko, I. (1923) Naochna tablytsia mylozvuchnosti ukrainskoi movy Dlia shkoly y samonavchannia. [The graphic table of the delightfulness of the Ukrainian language for school and self-education]. Zhovkva. Drukarnia Ottsiv Vasyliian, 1923. [In Ukrainian]. 8. Prokopova, L. (2010). Shche raz pro osnovnyi parametr mylozvuchnosti ukrainskoi movy. [One more time about the Ukrainian language harmony]. Ukrainska mova. [Ukrainian Language], 2, 76-80. URI: http://dspace.nbuv. gov.ua/handle/123456789/37707 [In Ukrainian]. 9. Samiilenko, V. (2003). Dbaimo pro fonetychnu krasu movy. [Let's talk about the phonetic beauty of speech]. Urok ukrainskoi. [Ukrainian lesson], 2. 28-29. [In Ukrainian]. 10. Serbenska O. (2016). Osnovni parametry mylozvuchnosti ukrainskoi movy. [Main options of ukrainian language euphony]. Tele- ta radiozhurnalistyka. [TV and radio journalism], 15, 258-266. URI: http://nbuv.gov.ua/UJRN/ Tir_2016_15_38. [In Ukrainian]. 11. Tymoshenko, T. D. (1952). Zasoby mylozvuchnosti (evfonii) ukrainskoi movy. [Meadows of sonority (euphony) of the Ukrainian language]. Ukrainska mova v shkoli, [Ukrainian Language at School], 4, 3-14. URI:http://zbruc.eu/ node/41915. [In Ukrainian]. 12. Totska, N. I. Zasoby mylozvuchnosti ukrainskoi movy. [Meadows of sonority of the Ukrainian language]. Ukrainske movoznavstvo. [Ukrainian Linguistics],22,3-URI: http://www.mova.ukr/htm/04/71.htm [In Ukrainian]. 13. Фарioн, I. Д. (2007). Farion I. D. Vslukhaimos u zvuky kriz viky. [Listen to the Sounds Through the Ages]. Ukrainskyi smysl: Naukovo-populiarnyi linhvokulturolohichnyi shchokvartalnyk. [Ukrainian Sense]. Dnipropetrovs'k: Vyd-vo DNU, 4, 2-14 [In Ukrainian]. 14. Shevelov, Yu. (2002) Istorychna fonolohiia ukrainskoi movy. [A historical phonology of the Ukrainian language] Kharkiv: Akta, XII, 1054 [In Ukrainian].

Скаб Мар'ян Стефанович - доктор філологічних наук, професор, завідувач кафедри історії та культури української мови, Чернівецький національний університет імені Юрія Федьковича; вул. М. Коцюбинського, 2, Чернівці, 58012, Україна.

E-mail: skabm1@gmail.com

https://orcid.org/0000-0002-9303-6154

Skab Marian Stefanovych - Doctor of Philology, Professor, Head of the History and Culture of the Ukrainian Language Department, Yurii Fedkovych Chernivtsi National University; M. Kotsiubynskyi Str., 2, Chernivtsi, 58012, Ukraine. 